УДК 37.015.3:378.147:796.011.3

В. В. Черняков, к. пед. н., доцент,

Т. П. Колодяжна, ст. викладач, Т. В. Дерябкіна, ст. викладач

\title{
ПСИХОЛОГО-ПЕДАГОГІЧНІ АСПЕКТИ СТАВЛЕННЯ ЗДОБУВАЧІВ ВИЩОЇ ОСВІТИ ДО ЗАНЯТЬ 3 ФІЗИЧНОГО ВИХОВАННЯ
}

Актуальність теми дослідження. Ефрективна реалізація провідної мети фрізичного виховання у вищих навчальних закладах передбачає здійснення розробки різноманітних концептуальних моделей моніторингу ставлення здобувачів вищої освіти до процесу фрізичного виховання.

Постановка проблеми. Значна кількість здобувачів вищої освіти не виявляють стійкої мотивації до систематичних занять з фрізичного виховання.

Аналіз останніх досліджень і публікацій. Питання розв'язання концепції ставлення до занять з фрізичного виховання розглядалися такими дослідниками як М. Й. Варій, А. К. Маркова та інші (актуальність знань у концепції ставлення), Л. М. Прогонюк, Л. М. Мустафріна, А. М. Сільвейстр, А. М. Моклюк (мотивація до навчання, фрізичного виховання), М. Й. Варій, Н. Корж (роль формування пізнавальних інтересів у концепції ставлення до занять ффізичними вправами), О. М. Леонтьєв, В. М. Мясищев (особистісні потреби у структурі ставлення), К. Г. Ніколаєв, Г. О. Єсіонова, Т. С. Брюханова, В. М. Лисяк та інші. (мотивація здобувачів вищої освіти до занять з фрізичного виховання) та інші.

Виділення недосліджених частин загальної проблеми. Малодослідженими залишаються психологічні та педагогічні аспекти ставлення здобувачів вищої до занять $з$ фрізичного виховання, розвитку фізичних здібностей, дотримання здорового способу життя.

Постановка завдання. Мета публікації полягає у вивченні психолого-педагогічних аспектів ставлення здобувачів вищої освіти до занять з фрізичного виховання у процесі фрахової підготовки.

Виклад основного матеріалу. Розгляд проблеми ставлення здобувачів вищої освіти до занять з фізичного виховання у психолого-педагогічних дослідженнях передбачає вивчення його взаємозв'язку з такими психологічними властивостями особистості, як емоції, мотиви, інтереси, потреби, а також знаннями та навчальною діяльністю. Забезпечення ефективності процесу формування ставлення здобувачів до занять фізичними вправами здійснюється з урахуванням таких структурних компонентів: когнітивний, емоційний, мотиваційний, діяльнісний.

Висновки. Позитивне ставлення здобувачів вищої освіти до занять з фізичного виховання розглядається як важливий провідний компонент передумови фрормування здорового способу життя.

Ключові слова: фрізичне виховання; мотивація, ставлення.

\section{V. Cherniakov, Candidate of Pedagogical Sciences,} Associate Professor,

T. P. Kolodiazhna, Senior Lecturer, T. V. Deriabkina, Senior Lecturer

\section{PSYCHOLOGICAL AND PEDAGOGICAL ASPECTS OF HIGHER EDUCATION ATTITUDE TO PHYSICAL EDUCATION CLASSES}

Urgency of the research. Effective implementation of the leading goal of physical education in higher educational institutions involves the development of various conceptual models for monitoring the attitude of applicants of higher education to the process of physical education.

Target setting. A significant number of applicants for higher education do not show a stable motivation for systematic exercises in physical education.

Actual scientific researches and issues analysis. The issues of solving the concept of attitude to physical education classes were considered by such researchers as M. Y. Variy, A. K. Markov, etc (relevance of knowledge in the concept of attitude), L. M. Progonyuk, L. M. Mustafin, A. M. Silveistr, 
A. M. Moklyuk (motivation to study, physical education), M. Y. Variy, N. Korzh (the role of forming cognitive interests in the concept of attitude to exercise), O. M. Leontiev, V. M. Mesishchev (personal needs in the structure of attitude), K. H. Nikolaev, H. O. Esionova, T. S. Brykhanova, V. M. Lysiak, etc. (motivation of applicants of higher education for physical education classes).

Uninvestigated parts of general matters defining. Psychological and pedagogical aspects of attitude of applicants of higher education, development of physical abilities, observance of healthy lifestyle remain little-researched.

The research objective. The purpose of the publication is to study the psychological and pedagogical aspects of attitude of applicants of higher education to classes on physical education in the process of professional training.

The statement of basic materials. Consideration of the problem of attitude of applicants of higher education to classes on physical education in psychological and pedagogical research involves studying its relationship with such psychological properties of the individual as emotions, motives, interests, needs, as well as knowledge and educational activities. Ensuring the effectiveness of the process of formation of attitude of applicants to exercise is carried out taking into account the following structural components: cognitive, emotional, motivational, active.

Conclusions. The positive attitude of applicants of higher education to physical education classes is considered as an important leading component of the prerequisite for the formation of a healthy lifestyle.

Keywords: physical education; motivation; attitude.

DOI: 10.25140/2412-1185-2019-2(14)-84-90

Актуальність теми дослідження. Фізичне виховання - це педагогічний процес, спрямований передусім на формування позитивного ставлення здобувача вищої освіти до цінностей фізичної культури і відповідно до занять фізичними вправами.

У теорії ставлень, розробленій В. М. Мясищевим, поняття «ставлення» розглядається як базова категорія. Ним було досліджено проблему про сутність зв'язку ставлень і психічних процесів, здійснено аналіз типів ставлень, подано різновиди типології людей та встановлено їх зв'язок зі ставленням, досліджено особливості розвитку ставлень та їх фрормування. Він стверджував,що психологічні особливості ставлення людини до суспільних процесів у розгорнутому вигляді являють собою цілісну систему індивідуальних, вибіркових, свідомих зв'язків особистості з різними фоормами об'єктивної дійсності. На його думку, предметом ставлень може бути увесь спектр діяльності людини [1].

Своїми дослідженнями В. М. Мясищев доводить, що у процесі навчальній діяльності чітко прослідковується загальна закономірність: функціональні можливості людини у будь-якому напрямі діяльності можуть бути визначені лише за наявності його активно-позитивного ставлення до виконання завдання [1].

Процес фрізичного виховання здобувачів вищої освіти має ґрунтуватися на перевагах їх усвідомленого ставлення до занять з фізичного виховання, в основі якого повинно бути прагнення до забезпечення покращення рівня власного фрізичного розвитку та підвищення мотивації студентів до здорового способу життя.

Ефективна реалізація провідної мети фрізичного виховання у вищих навчальних закладах передбачає здійснення розробки різноманітних концептуальних моделей моніторингу ставлення здобувачів вищої освіти до процесу фізичного виховання.

Постановка проблеми. Значна кількість здобувачів вищої освіти не виявляють стійкої мотивації до систематичних занять з фрізичного виховання. Дослідження структури формування мотивації до систематичних занять з фізичного виховання $є$ важливим завданням сьогодення

Аналіз останніх досліджень і публікацій. При визначенні структури ставлення у психологопедагогічних дослідженнях виявлено його взаємозв'язок з такими психологічними властивостями особистості, як емоції, мотиви, інтереси, потреби, а також знаннями та навчальною діяльністю. Так, наприклад, А. К. Маркова, М. Й. Варій та інші зазначають, що справжньою причиною негативного ставлення до навчального процесу не рідко $€$ відсутність знань. Знання - це образи предметів, явищ матеріального світу та їх взаємозв'язків, образи дій людини з цими предметами. Викладачу необхідно не лише у загальному вигляді вказати на недостатність знань, а якомога 
точніше визначати, чого саме у знаннях даної особистості не вистачає. Це тим більш важливо, оскільки деякі прогалини у знаннях можуть бути причиною небажання отримувати знання [2; 3].

Мотив є стимулом до дії, спрямованим на задоволення потреб та інтересів особистості. Мотив забезпечує активні ставлення, сприяє реалізації намірів і мети діяльності. У мотиві проявляється не лише напрямок ставлення - позитивний чи негативний. Мотивація характеризується компонентами, що містяться у цьому ставленні. Будь-який мотив відображає певний напрямок і зміст ставлення. Необхідною умовою характеристики ставлень особистості $\epsilon$ розкриття зв'язку між мотивами та діяльністю [4; 5].

М. Й. Варій аналізує ставлення у взаємодії із пізнавальними інтересами, які виникають при позитивному ставленні до того чи іншого об'єкту. Інтереси відображають дійсність, а людина, відтворюючи їі, обов'язково проявляє своє ставлення до неї. Суб'єктивно інтерес проявляється на емоційному фоні, якого набуває процес пізнання. Задоволення інтересу не веде до його згасання, а викликає появу нових інтересів, які відповідають значно вищому рівню пізнавальної діяльності. Інтерес у динаміці свого розвитку може перетворюватися у схильність як прояв потреби у здійсненні діяльності, викликаної інтересом [3; 6].

Досліджуючи потреби у структурі ставлення, О. М. Леонтьєв, В. М. Мясищев та інші зазначають, що ставлення впливає на виникнення якісно нової психічної форми потреб, коли людину стимулює до дії не безпосередня потреба у чомусь, а прагнення до нового переживання - до оволодіння (наприклад, новими рухами), до досягнення (наприклад, успіху). Таке прагнення вважається формою самовираження ставлення, його активного функціонування. Із задоволенням певних потреб особистості змінюється й її ставлення [1].

Проблеми дослідження мотивації здобувачів вищої освіти до занять з фізичного виховання у своїх наукових працях висвітлюють Т. С. Брюханова, Г. О. Єсіонова, В. М. Лисяк, К. Г. Ніколаєв та інші. Здійснені ними дослідження у цьому напрямку розкривають особливості специфріки фрізичного виховання, що полягають в усвідомленні інформації, яка стає спонукальною мотивацією до занять з фрізичного виховання, використання засобів фрізичного виховання, що сприятиме досягненню успіху у особистих і суспільних цілях $[7 ; 8 ; 9 ; 10]$.

Виділення недосліджених раніше частин загальної проблеми. Проте на жаль, не зважаючи на значний внесок науковців у розробку моделей визначення ставлення та мотивації здобувачів вищої освіти до занять з фізичного виховання й досі залишаються не розв'язаними окремі питання дослідження ставлення до занять з фізичного виховання відповідно до фахової спрямованості.

Малодослідженими залишаються психологічні та педагогічні аспекти ставлення здобувачів вищої освіти до занять з фрізичного виховання, розвитку фізичних здібностей, дотримання здорового способу життя.

Постановка завдання. Результати аналізу наукової літератури з питань дослідження мотивації здобувачів вищої освіти до занять з фізичного виховання свідчать, що ця проблема потребує постійної уваги науковців.

Мета публікації полягає у вивченні психолого-педагогічних аспектів ставлення здобувачів вищої освіти до занять з фрізичного виховання у процесі фрахової підготовки.

Виклад основного матеріалу. Ставлення здобувачів вищої освіти до занять з фізичного виховання $є$ однією із актуальних соціально-педагогічних проблем навчально-виховного процесу, подальшого розвитку і розширення масової оздоровчої, фрізкультурної і спортивної роботи у вищій школі.

Навчальний процес на заняттях з фізичного виховання стає діяльністю, якщо здобувач під час набуття знань оволодіває новими способами навчальних дій, які витікають від самостійно поставлених навчальних завдань, оволодіває прийомами самоконтролю та самооцінки своєї навчальної діяльності. Отже, навчання здійснюється як діяльність тоді, коли здобувач оволодіває не лише знаннями, але і способами їх набуття; якщо ці способи не подаються йому у готовому вигляді, а самостійно вибудовуються самим здобувачем і витікають 3 поставленого ним навчального завдання; якщо здобувач засвоює не лише способи роботи із знаннями, але й способи роботи із самим собою, тобто прийоми самоконтролю та самооцінки. Навчання, організоване як активна діяльність, суттєвою мірою визначає ставлення здобувачів до нього та, зокрема, до процесу фрізичного виховання.

Аналіз практичного досвіду показує, що у формуванні в здобувачів позитивного ставлення до занять з фізичного виховання важливу роль відіграє цікаво побудований процес навчання. 
Освітні завдання фізичного виховання у ВНЗ умовно поділяються на дві групи. До першої групи відносяться завдання, спрямовані на вдосконалення рівня рухової діяльності здобувачів, збагачення їх навичками життєво важливих рухів, формування готовності швидко та ефективно засвоювати нові рухові уміння. До другої групи належать завдання, що передбачають озброєння здобувачів теоретичними знаннями й практичними уміннями використовувати засоби фізичної культури для зміцнення здоров'я, загартування організму, складання правильного режиму праці й відпочинку та підвищення працездатності. Чим більше знань засвоюють здобувачі, тим глибше у них розвивається абстрактно-теоретичний компонент рухової діяльності, вищими є результати у фрормуванні умінь та навичок, розвитку фізичних якостей, вихованні позитивного ставлення до занять з фізичного виховання.

На формування ставлення позитивно впливають емоційні переживання здобувачів. Повнота і глибина формування позитивних емоцій, відчуттів та морально-вольових якостей здобувачів вищої освіти перебувають у прямій залежності від конкретних умов організації навчального процесу та позанавчальної фрізкультурно-масової роботи. Зазначимо, що за умов умілої, методично правильної організації навчання у здобувачів створюються оптимальні емоційні стани, що сприяють засвоєнню ними програмного матеріалу, позитивно впливають на процес формування рухових навичок. I навпаки, астенічні емоції демобілізують вольові зусилля здобувачів, знижують їхню рухову активність, гальмують процес формування правильних рухових навичок. Найбільш ефективним засобом формування емоційної сфери здобувачів у процесі фізичного виховання $є$ змагальний метод проведення занять, який сприятливо впливає на швидкість рухових реакцій, зростання м'язової сили, покращення координації рухів, підвищення здатності до сприйняття і відтворення рухів та формування рухових навичок. Слід зазначити, що головна роль у створенні оптимальних емоційних станів здобувачів засобами фізичної культури значною мірою належить викладачу, його особистісним якостям, педагогічній майстерності та досвіду.

Для здобувачів головною потребою, яка реалізується у ході занять з фізичного виховання, $\epsilon$ потреба у самоствердженні, самовираженні, зацікавленість в оцінці іншими людьми. Тому в процесі виховної роботи необхідно підтримувати їхній інтерес до занять і таким чином планувати навчання та змагання, щоб здобувачі постійно відчували позитивну динаміку свого фрізичного розвитку, власної спортивної майстерності.

Дослідження проблеми виховання у здобувачів потреби фізичного вдосконалення, має ґрунтуватись насамперед на тому, що саме у процесі фрахової підготовки найуспішніше можна здійснити перехід від елементарних потреб кінезофілії до усвідомленої потреби в фрізичному вдосконаленні як одному 3 найважливіших моментів самовиховання. Слід зазначити, що потреби здобувачів вищої освіти вирізняються більшою усвідомленістю, стійкістю, активністю, дієвістю. Водночас фрормування потреби фізичного вдосконалення у здобувачів може бути досягнуто за умови органічного взаємозв'язку навчальної та позанавчальної фрізкультурномасової роботи, а також єдності вимог фрахової підготовки до рівня фізичної підготовленості.

Вивчення педагогічної літератури дозволяє дати робоче визначення ставлення здобувачів вищої освіти до занять з фрізичного виховання як цілісної системи індивідуальних, вибіркових, свідомих зв'язків особистості з різними формами фрізичної культури, які характеризують внутрішню позитивну позицію в ії оцінці та трансфрормуються в особистісні цінності. Основними структурними компонентами позитивного ставлення здобувачів до занять з фрізичного виховання (Табл. 1) є: когнітивний компонент; емоційний компонент; мотиваційний компонент; діяльнісний компонент $[1 ; 2 ; 5 ; 6 ; 7 ; 8 ; 9 ; 10]$.

Фізичне виховання здобувачів на заняттях з фізичного виховання має бути побудоване 3 урахуванням результатів вихідних обстежень рівнів розвитку ставлення здобувачів до занять 3 фрізичного виховання. Умовний розподіл здобувачів на п'ять груп відповідно до цих рівнів дозволяє диференційовано підійти до вибору змісту, фрорм і методів навчання на кожен з його компонентів. Тому на початковому етапі виховної роботи, коли у здобувачів спостерігається негативне й індиферентне ставлення до занять 3 фізичного виховання, у першу чергу створюються сприятливі умови для подолання невпевненості у виконанні окремої вправи, застосовуються заохочувальні впливи, які забезпечують виникнення позитивних емоцій, почувань і мотивів занять фізичними вправами. 
Структура позитивного ставлення здобувачів до занять 3 фізичного виховання

Таблиця 1

\begin{tabular}{|l|l|}
\hline \multicolumn{1}{|c|}{ Структурні компоненти } & \multicolumn{1}{c|}{ Особистісні утворення } \\
\hline Когнітивний & Система знань з фрізичної культури \\
\hline Емоційний & Емоційні переживання \\
\hline \multirow{2}{*}{ Мотиваційний } & $\begin{array}{l}\text { Мотиви занять фрізичними вправами } \\
\text { Інтерес до занять з фізичного виховання } \\
\text { Потреба у фрізичному вдосконалені }\end{array}$ \\
\hline Діяльнісний & Свідома активність на заняттях з фрізичного виховання \\
Джерело: $[1 ; 2 ; 5 ; 6 ; 7 ; 8 ; 9 ; 10]$ & Звичка до занять з фрізичного виховання \\
\hline
\end{tabular}

Розв'язання таких завдань вимагає від викладачів застосування зовнішніх стимулів (відповідно до сутності й завдання навчання) та забезпечення мотивації здобувачів до усвідомлених занять фізичними вправами. Провідне місце у переліку таких стимулів посідають такі: створення обстановки успіху; гласність навчальних здобутків; заохочення здобувачів; переконання за допомогою слова і особистого прикладу; оцінка результатів навчання.

Цьому сприяють також: створення загальної позитивної атмосфери на заняттях з фізичного виховання; доброзичлива співпраця викладача та здобувачів у процесі навчальної діяльності; підтримка порадами викладача, які спонукають здобувачів до усвідомленого прагнення виконувати фізичні вправи; цікава фрорма викладення навчального матеріалу; емоційна, яскрава мова викладача; використання рухливих та народних ігор, змагальних ситуацій тощо.

Для подолання побоювання здобувачів під час виконання рухових завдань та невпевненості у власних силах, що спричинені невдалими спробами виконання, на заняттях з фрізичного виховання доцільно створювати варіанти навчальних ситуацій, в при подолання яких здобувач досягає успіху. На заохочення підтримувати бажання виконувати фрізичні вправи позитивно впливає облік досягнень здобувачів. Викладачем здійснюється розробка індивідуальних завдань відповідно до рівня підготовленості, які $є$ для здобувачів особистою перспективою. Перевага такого підходу полягає у тому, що за умов систематичності та сумлінного ставлення до занять кожен здобувач може поліпшити свій результат і досягнення кращих здобувачів не перекреслює його успіх. Завдяки тому, що здобувачі залежно від своїх даних рухаються до мети поступово, відкривається можливість забезпечити успіх усім без винятку незалежно від рівня їхньої підготовленості. Для гарантії успіху викладач з фізичного виховання має володіти інформацією про здатність кожного здобувача, уміти допомагати усувати недоліки у фрізичному розвитку, виявляти їх причини й пропонувати шляхи для їх усунення.

Важливим стимулом виховання в здобувачів позитивного ставлення до занять фізичними вправами є оцінка їхніх досягнень. Тому для ії̈ підвищення робиться все, щоб про успіх та прогрес здобувачів знали й інші здобувачі. В іншому випадку особисте досягнення не забезпечує дієвого заохочувального впливу на збільшення рівня активності здобувача на заняттях з фрізичного виховання. Найбільш дієвою формою гласності є оцінювання успішності 3 фізичного виховання. До таблиці систематично заносяться початкові та поточні результати здобувачів, які доводяться до їх відома й заохочуються шляхом морального стимулювання. Тимчасове невиконання навчальних нормативів не потрапляє до таблиці й обговорюється зі здобувачем наодинці з наданням йому конкретної практичної допомоги з боку викладача.

Для забезпечення дієвої ефективності стимулювання здобувачів викладач має дотримуватися таких правил: застосовувати дидактичні можливості диференційованого підходу, завдяки якому здобувачів з низьким рівнем фізичного розвитку заохочуються бодай за найменші успіхи; враховувати успіх досягнень, які $\epsilon$ наслідком прикладення зусиль і сумлінності здобувачів у процесі виконання індивідуальних та вирішення навчальних завдань у складі групи; забезпечувати гласність у заохоченнях; знаходити об'єктивні доводи для стимулювання максимальної кількості здобувачів; аргументувати кожне заохочення і супроводжувати його методичними вказівками, спрямованими на покращення якості виконання рухової дії; досягати того, щоб заохочення було конкретним і об'єктивним, яке у такому випадку спонукає здобувачів до досягнення значно вищих навчальних результатів; робити усе, щоб заохочення сприяло вихованню в здобувачів відповідальності, розвитку уміння критично оцінювати зроблене і 
досягати нових результатів; дотримуватися обґрунтованості і справедливості заохочення з тим, щоб воно сприяло не тільки виконанню здобувачами навчальних завдань, але й прояву ними працелюбності, ініціативності та інших позитивних якостей; враховувати особистісні та індивідуальні якості здобувачів, адже одне і те ж заохочення неоднаково впливає на активність здобувачів на заняттях з фрізичного виховання.

Основним джерелом виникнення інтересу до занять з фрізичного виховання у здобувачів $\epsilon$ їхня природна потреба в рухах, другим - потреба у розвагах, яка найкраще задовольняється під час занять рухливими і спортивними іграми. Третім джерелом $€$ потреба у пізнанні нових відчуттів. Правильне використання цих потреб забезпечує яскраве емоційне забарвлення процесу навчання. На їх основі розвивається початкова стадія психологічного механізму формування інтересу до занять з фрізичного виховання.

Ефективність навчального процесу у вихованні в здобувачів інтересу до занять з фізичного виховання значною мірою залежить й від раціонального розподілу часу на його підготовку й проведення. Забезпечення економії часу передбачає: своєчасну підготовку спортивного залу, спортмайданчика, необхідного обладнання та інвентарю для заняття, виходячи з його основної мети та навчальних завдань; своєчасність підготовки здобувачів до заняття; конкретне та зрозуміле викладення нового навчального матеріалу; раціональна кількість повторень кожної рухової дії; збільшення щільності заняття під час вивчення та вдосконалення вправ шляхом поділу групи на підгрупи.

Провідну роль у вихованні в здобувачів інтересу до занять з фізичного виховання у процесі навчання відіграє якість проведення занять. Значною мірою вона залежить від раціонального планування й доцільного застосування протягом заняття методів і прийомів, що забезпечують виховну функцію, достатньої кількості й належного стану фрізкультурного обладнання та інвентарю, оформлення залу і спортивних майданчиків. Важливого значення при цьому набуває гарний і зручний одяг здобувачів та викладача, цікаво організований процес навчання руховим діям. Це викликає в них установку, потяг та бажання активно працювати над своїм фрізичним удосконаленням.

На початкових стадіях становлення інтересу в здобувачів домінує зацікавленість самим процесом виконання фізичних вправ. Саме тому навчання слід проводити так, щоб у свідомості здобувачів залишався позитивний емоційний слід. Такий підхід дозволяє створити сприятливі умови для їх вольової підготовки на здолання труднощів під час самостійних занять і полегшує роботу викладача на наступних стадіях розвитку інтересу до занять з фрізичного виховання.

Отже, реалізація у ході навчального процесу розвитку кожного компонента ставлення здобувачів до занять з фізичного виховання дозволяє викладачу знаходити оптимальні шляхи його формування у процесі фахової підготовки у вищому навчальному закладі. Відносний розподіл здобувачів на п'ять груп у відповідності до їх рівнів сформованості ставлення до занять з фрізичного виховання дозволяє забезпечити диференційований підхід до вибору змісту, фрорм і методів навчально-виховної роботи з кожним з його компонентів. Виходячи з цього, спеціальні виховні засоби добираються викладачем з урахуванням особистісних та індивідуальних якостей кожного здобувача, а також результатів обстежень рівнів розвитку ставлення здобувачів до занять з фізичного виховання. Це створює сприятливі умови для організації самовиховання здобувачів у ході навчального процесу й поза ним.

Висновки. Отже, на основі вищевикладеного, слід зазначити, що знання й уміле врахування та використання викладачами вищого навчального закладу у навчально-виховному процесі психолого-педагогічних аспектів формування ставлення здобувачів вищої освіти до занять 3 фізичного виховання дозволить значною мірою підвищити рівень мотивації до занять фізичними вправами та сформувати стійку спрямованість на здоровий спосіб життя.

Література

1. Мясищев, В. Н. Психология отношений / В. Н. Мясищев. - Москва-Воронеж : Изд-во: МПСИ, МОДЭК, 2011. - 400 с.

2. Маркова, А. К. Методы изучения и формирования мотивации учения школьников // Формирование мотивации учения / А. К. Маркова, Т. А. Матис, А. Б. Орлов. - М. : Просвещение, 1990. - С. 5-77.

3. Варій, М. Й. Загальна психологія: підр. [для студ. вищ. навч. закл.] / М. Й. Варій - З-тє вид. - К. : Центр учбової літератури, 2009. - 1007 с. 
4. Прогонюк, Л. Н. Исследование мотивации достижения в условиях спортизированного физического воспитания в общеобразовательной школе / Л. Н. Прогонюк, Л. Н. Мустафина // Физическая культура: воспитание, образование, тренировка. - 2002. - № 1. - С. 15-16.

5. Сільвейстр, А. М. Мотивація навчання студентів як психолого-педагогічна проблема / А. М. Сільвейстр, А. М. Моклюк // Наукові записки. Серія: Проблеми методики фізико-математичної і технологічної освіти.

- Кіровоград : РВВ КДПУ ім. В. Винниченка, 2014. - Випуск 5. - Частина 1. - С. 152-158.

6. Корж, Наталія. Формування пізнавальної активності в студентів технічних спеціальностей до цінностей фізичної культури / Наталія Корж // Фізичне виховання, спорт і культура здоров'я у сучасному суспільстві : зб. наук. пр. Волин. нац. ун-ту ім. Лесі Українки / уклад. А. В. Цьось, С. П. Козіброцький. - Луцьк : Волин. нац. ун-т ім. Лесі Українки, 2012. - № 1 (17). - С. 45-49.

7. Брюханова, Т. С. Підвищення мотивації студентів до здорового способу життя шляхом впровадження спортивно-орієнтованих технологій навчання / Т. С. Брюханова // Науковий вісник Ужгородського університету. Серія: «Педагогіка. Соціальна робота». - 2016. - Випуск 2 (39). - С. 39-40.

8. Єсіонова, Г. О. Дослідження мотивів студентів до занять фізичними вправами / Г. О. Єсіонова // Педагогіка, психологія та медико-біологічні проблеми фізичного виховання i спорту: наукова монографрія за редакцією проф. Єрмакова С. С. - Харків: ХДАДМ (ХХПІ), 2006. - № 10. - С. 96-99.

9 Лисяк В. М. Динаміка мотивації до занять фізичною культурою у студентів вищих навчальних закладів за весь період навчання / В. М. Лисяк // Слобожан. наук.-спорт. вісн. - 2013. - № 3. - С. 199-203.

10. Ніколаєв, К. Формування мотивації до занять фізичною культурою студентів вищих навчальних закладів не фізкультурного профілю / К. Ніколаєв // Науковий вісник Миколаївського державного університету імені В. Сухомлинського. - 2010. - Вип. 1. - С. 135-142.

\section{Reference}

1. Miasishchev, V. N. (2011). Psikhologiia otnoshenii [Relationship Psychology]. Moscow-Voronezh: Izd-vo: MPSI, MODEK [in Russian].

2. Markova, A. K., Matis, T. A., Orlov, A. B. (1990). Metody izucheniya i formirovaniya motivatsii ucheniya shkolnikov [Methods of studying and motivating the teachings of schoolchildren]. Formirovanie motivatsii ucheniya - Motivating the teachings. (pp. 5-77). Moscow: Prosveshchenie [in Russian].

3. Varii, M. Y. (2009). Zahalna psykholohiia [General psychology]. Kyiv: Tsentr uchbovoi literatury [in Ukrainian].

4. Progoniuk, L. N. Mustafina, L. N. (2002). Issledovanie motivatsii dostizheniia v usloviiakh sportizirovannogo fizicheskogo vospitaniia $v$ obshcheobrazovatelnoi shkole [Study of motivation to achieve in the context of sportsed physical education in a comprehensive school]. Fizicheskaia kultura: vospitanie, obrazovanie, trenirovka - Physical culture: education, education, training, 1, 15-16 [in Russian].

5. Sileistr, A. M., Mokliuk, A. M. (2014). Motyvatsiia navchannia studentiv yak psykholoho-pedahohichna problema [Motivation of students' education as a psychological and pedagogical problem]. Naukovi zapysky. Seriia : Problemy metodyky fizyko-matematychnoi i tekhnolohichnoi osvity - Scientific notes. Series: Problems of methodology of physical, mathematical and technological education, 1, 152-158 [in Ukrainian].

6. Korzh, Nataliia. (2012). Formuvannia piznavalnoi aktyvnosti $v$ studentiv tekhnichnykh spetsialnostei do tsinnostei fizychnoi kultury [Formation of cognitive activity in students of technical specialties to the values of physical culture]. Fizychne vykhovannia, sport i kultura zdorovia u suchasnomu suspilstvi - Physical Education, Sport and Health Culture in Modern Society, 1(17), 45-49 [in Ukrainian].

7. Briukhanova, T. S. (2016). Pidvyshchennia motyvatsii studentiv do zdorovoho sposobu zhyttia shchliakhom vprovadzhennia sportyvno-oriientovanykh tekhnolohii navchannia [Increasing students motivation for a healthy lifestyle by introducing sports-oriented learning technologies]. Naukovyi visnyk Uzhhorodskoho universytetu. Seriia «Pedahohika. Sotsialna robota» - Scientific Bulletin of Uzhhorod University. Series: Pedagogy. Social Work, 39, 39-40 [in Ukrainian].

8. Yesionova, H. O. (2006). Doslidzhennia motyviv studentiv do zaniat fizychnymy vpravamy [Study of students' motives for exercise]. S.S. Yermakov (Eds.). Pedahohika, psykholohiia ta medyko-biolohichni problem fizychnoho vykhovannia I sportu - Pedagogics, psychology, medical-biological problems of physical training and sports, 10, 96-99 [in Ukrainian].

9. Lysiak, V. M. (2013). Dynamika motyvatsii do zaniat fizychnoiu kulturoiu u studentiv vyshchykh navchalnykh zakladiv za ves period navchannia [Dynamics of motivation for physical culture classes in students of the higher educational institutions during the whole period of studies]. Slobozhanskyi naukovo-sportyvnyi visnyk - Slobozhansky Scientific and Sports Bulletin, 3, 199-203 [in Ukrainian].

10. Nikolaiev, K. H. (2010). Formuvannia motyvatsii do zaniat fizychnoiu kulturoiu studentiv vyshchykh navchalnykh zakladiv ne fizkulturnoho profiliu [Formation of motivation for physical culture of students of higher educational institutions not physical training profile]. Naukovyi visnyk Mykolaivskoho derzhavnoho universytetu imeni V. O. Sukhomlynskoho - Scientific Bulletin of the Nikolayev National University named after V.O. Sukhomlynsky, 1, 135-142 [in Ukrainian].

Надійшла 14.11.2019

Бібліографрічний опис для цитування:

Черняков, В.В.Психолого-педагогічні аспекти ставлення здобувачів вищої освіти до занять з фізичного виховання / В. В. Черняков, Т. П. Колодяжна, Т. В. Дерябкіна // Проблеми соціальної роботи: фрілософія, психологія, соціологія. - 2019. - № 2 (14). - С. 84-90. 